\title{
A KÜLÖNLEGES MINŐSÉGÜ ÉLELMISZEREK VIDÉKFEJLESZTÉSBEN BETÖLTÖTT SZEREPE
}

\author{
Dr. PhD. Panyor Ágota \\ föiskolai docens, Szegedi Tudományegyetem Mérnöki Kar
}

\section{Summary}

In our work the concept of "special foods" - in a wider sense - is defined as foods not yet widespread in public consumption. They represent special quality, which - in our opinion - may derive from traditions, from geographical properties related to food production or from the organic nature of production.

The main characteristics of individual groups of special foods (foods originating from organic production, geographical indications products, traditional and local foods) are reviewed and proposals are made for improving the quality of life and for increasing the population-retaining capacity in rural regions.

Special foods represent a higher added value, their production offers a possibility for inhabitants in rural areas to make agricultural production more diverse, to popularize the products of disadvantaged regions and to increase the farmers' income.

\section{BEVEZETÉS}

A helyes és egészséges táplálkozás a kultúrált élet egyik tartozéka, hiszen az elfogyasztott élelmiszer az egészség és a betegség forrása is lehet. A globalizáció egyik hatásaként egyre több import élelmiszer kerül a magyar fogyasztóhoz, így nehéz a termékek minőségének garantálása. Az újra és újra felmerülö élelmiszerbotrányok megnövelték a fogyasztók, és az élelmiszerpiac többi résztvevőjének az élelmiszereink minőségére vonatkozó érzékenységét. Ezért elötérbe kerül a biztonságos és jó minöségü élelmiszerek iránti igény, ami azt jelenti, hogy a termelés, az elóállítás és a forgalmazás teljes folyamatában biztosítani szükséges, hogy az élelmiszer ne veszélyeztesse a fogyasztó egészségét. A mai piaci versenyhelyzetben a termékek egyedi tulajdonságai - amelyek többnyire generációk alatt jöttek létre és maradtak fenn - az elismert és állandó minőséget fémjelzik, értéket képviselnek.

A ,különleges élelmiszerek" fogalmát - tágabb értelemben - úgy definiálhatjuk, mint olyan élelmiszerek, amelyek még nem terjedtek el a közfogyasztásban. Különleges minőséget jelentenek, amely véleményünk szerint eredhet a hagyományokból, az élelmiszer előállításhoz kapcsolódó földrajzi tulajdonságokból, vagy az elöállítás organikus jellegéből. Így jelen munka kiterjed a hagyományos és tájjellegü élelmiszerekre, az ökológiai gazdálkodásból származó élelmiszerekre, valamint a földrajzi árujelzös termékekre.

Az említett különleges élelmiszerek látszólag nagyon eltérőek, de mégis több jellemző az, amely összeköti őket és így egységes rendszerbe sorolhatók. Általános jellemzöjük, hogy kis mennyiségben gyártott termékek, az előállításuk során magas az élőmunkaigény, amely az árakban is testet ölt, tehát a tömegtermékekhez viszonyítva magasabb árakkal találkozhatunk ezen termékkörök esetében. További jellemzöjük, hogy kis sorozata folytán piaci rések, (niche-k) kitöltésére alkalmasak és így a termelő nincs alávetve a skálaintenzitás és a méretgazdaságosság követelményeinek. 


\section{ŌKOLÓGIAI GAZDÁLKODÁSBÓL SZÁRMAZÓ ÉLELMISZEREK}

Német kutatók arra a megállapításra jutottak, hogy az élelmiszerek okozta betegségek száma az ökotermékek fogyasztásával mintegy felére csökkenthető. Ez annak köszönhető, hogy azokban lényegesen kisebb a rizikótényezőnek számitó hormonkészítmények, vegyszermaradványok, baktériumok és vírusok, valamint gyógyszerek aránya (Eberle Reuter, 2004).

A bio/öko/organikus kifejezések szinonim fogalmak, ugyanakkor a szakemberek néhány évvel ezelött megállapodtak, hogy a „bio" elöszó helyett az „öko" változatot fogadják el. Ezt azzal is indokolták, hogy a „bio” fogalomként már foglalt a természettudományok részére, valamint az ökogazdálkodásnak átfogó értelmezését kell használni, ugyanis a már átált területeken és az ott termett árun kívül az átállás alatti területeket és termékeket is magába kell foglalnia. Ugyanakkor meg kell említeni, hogy az angolszász országokban „organikus” termelésröl-termékekről beszélnek, sem a „bio”, sem az „öko" megnevezést nem használják.

Az ökológiai minősitésü élelmiszereket „mesterségesen elöállított” tartósítószerek, színezékek és adalékanyagok, radioaktív sugárzóanyagok és toxikus anyagokat tartalmazó, szintetikus növényvédő szerek nélkül állítják eló, kizárják a genetikailag módosított szervezetek, antibiotikumok és növekedésserkentők használatát.

1991. június 24-én jelent meg a 2092/91/EGK számú a mezőgazdasági termékek ökológiai termeléséről, valamint a mezőgazdasági termékeken és élelmiszereken erre utaló jelölésekröl szóló rendelet. Ez hivatalosan, nemzetközi szinten is elismeri az ökológiai gazdálkodás létjogosultságát, és az Európai Unión kívül is számos ország számára fontos.. A rendelet határozza meg azokat a minimális normákat, amelyeket teljesíteni kell annak érdekében, hogy a terméket a piacon ökológiai gazdálkodásból származónak ismerhessék el, és annak megfelelően jelöljék.

Az ökológiai szemléletủ gazdálkodás Magyarországon a nyolcvanas évek elején mozgalomként indult. Azóta jelentős mértékủ növekedés következett be mind az ellenőrzött ökogazdálkodást folytató vállalkozások számában, mind a mủvelt földterület nagyságában. Az 2000. évi 47221 hektár ökológiai területhez viszonyitva folyamatos dinamikus növekedés volt megfigyelhetỏ 2004-ig. Harmadik éve azonban csökkenö tendenciát mutat hazánkban az ökológiailag ellenörzött területek nagysága, melynek egyik fö oka az ökológiai gazdálkodás támogatási forrásainak drasztikus csökkenése.

\section{1. ábra: Az ellenőrzött ökológiai területek alakulása}

\begin{tabular}{|c|c|c|c|c|c|c|c|c|}
\hline Év & 2000. & 2001. & 2002. & 2003. & 2004. & 2005. & 2006. & 2007. \\
\hline $\begin{array}{c}\text { Ellenỏrzött } \\
\text { terület (ha) }\end{array}$ & 47.221 & 79.178 & 103.672 & 113.816 & 128.690 & 122.615 & 116.197 & 111.873 \\
\hline $\begin{array}{c}\text { Vállalkozá- } \\
\text { sok száma }\end{array}$ & 471 & 764 & 995 & 1.155 & 1.420 & 1.353 & 1.249 & 1.203 \\
\hline
\end{tabular}

Forrás: www.biokontroll.hu 
$\mathrm{Az}$ ismert és közzétett 2007. évi adatok alapján elmondhatjuk, hogy a hazai ellenőrzött, átállt területek hasznosítására jellemzõ a rétként, legelöként (57\%) és a szántóként (36\%) való hasznosítás. A szántóföldi növények esetében a gabonafélék közül az őszibúza és a tönkölybúza vetésterülete a legnagyobb, míg az ipari növények közül kiemelkedö a napraforgó és a repce részesedése. Az ültetvények mindössze 2\%-ot képviselnek az összes ökoterületen belül, melyek közül azonban a legjelentősebb a gyümölcs és bogyós ültetvények aránya, valamint a szőlö termőterülete (biokontroll.hu).

Az ökológiai mezőgazdaságban a növénytermesztés mellet az állattartás is szerves és meghatározó része a gazdálkodásoknak. Ma Magyarországon 134 gazdaság foglalkozik bioállatartással, összesen 16430 számosállat állománnyal. Nagyon fontos szerepet játszanak az állatok ebben a termelési formában, hiszen a természetes tápanyag és a munkaerö is nélkülözhetetlen a gazdák számára. A legtöbb farmon - az elöíásoknak megfelelöen szarvasmarhát és juhot, valamint kisebb arányban sertést tartanak.

Említést kell tenni a bio-méhészetekről is, amelyek szintén fontos szerepet töltenek be a hazai ökogazdálkodásban. Azonban megállapíthatjuk, hogy annak ellenére, hogy Magyarország egész területe alkalmas a méhészkedésre, igen kevés a számuk. 2007-ben 192 termelő foglalkozott a méhekkel, és 18838 méhcsalád volt nyilvántartva (biokontroll.hu).

\section{VÉDETT EREDETŨ ÉS FÖLDRAJZI JELZÉSŨ, VALAMINT SPECIÁLIS TULAJDONSÁGÚ ÉLELMISZEREK}

Sok ideje már annak, hogy egyes mezőgazdasági termékeket és élelmiszereket elkezdtek azon területek neveivel jelölni, ahol azokat elóállították vagy feldolgozták. Már a görögök és a rómaiak is a származási területük szerint nevezték el a borokat, az olajbogyót, az olívaolajat, a sajtokat, a halat és a hústermékeket, a gyümölcsöket, a kenyeret és sok más terméket, ezáltal biztositva azok minőségének megkülönböztetését. Tehát ők voltak az elsök, akik a származásra utaló elnevezéseket, illetve földrajzi jelzéseket kezdtek használni.

Magyarországon az 1997. évi XI. védjegytörvény és a 124/2007 (V. 31.) Kormányrendelet alapvetően olyan mezőgazdasági és élelmiszeripari termékek földrajzi megjelölésének védelmét szolgálja, amelynek jellegzetes tulajdonságai és sajátosságai a termőtájhoz és emberi tényezöihez kötődnek. Így az alábbi célokat szolgálja:

- a mezögazdasági termelés változatosabbá tétele,

- a jellegzetes és egyedi termékek elöállításának ösztönzése,

- a jellegzetes termékek nevének védelme,

- a gazdálkodók jövedelem viszonyának javítása,

- a vidéki lakosság lakóhelyén tartása,

- a fogyasztók pontos tájékoztatása (Zobor, 2004).

A védett eredetmegjelölésũ termékek esetében az elöállításnak, a feldolgozásnak egészen a késztermékig annak a meghatározott földrajzi területen kell történnie, melynek nevét a termék viseli. A termék minősége és jellemzői alapvetően vagy kizárólag az adott földrajzi környezetnek vagy származási helynek kell, hogy tulajdoníthatók legyenek. A termék minőségének és a földrajzi környezetnek közvetlen és elválaszthatatlạn kapcsolatban kell lennie (pl. pármai sonka, normandiai camembert).

A védett földrajzi jelzésủ termékeknél az elỏállitás vagy feldolgozás legalábi egy fázisának a meghatározott területen kell lezajlania. Ezen kívül erös és kauzális kapcsolatnak kell lennie a termék és az adott régió között. Ez a kapcsolat a termék belsó lényegéből fakadó hírnevének lehet tulajdonítható (pl. feketeerdei sonka, nürnbergi mézeskalács, bajor sör). 
Magyarország eddig 11 mezőgazdasági termék és élelmiszer földrajzi árujelzőjének közösségi szintủ oltalom iránti kérelmét nyújtotta be hivatalosan az Európai Bizottsághoz:

Hústermékek:

- Gyulai kolbász

- Csabai kolbász

- $\quad$ Szegedi téliszalámi

- Budapesti téliszalámi

Elsődleges termékek:

- Hajdúsági torma

- Gönci kajszibarack

- Makói vöröshagyma

Paprikák:

- $\quad$ Szegedi füszerpaprika-őrlemény

- Kalocsai füszerpaprika-őrlemény

Egyéb (mezögazdasági termék):

- $\quad$ Szöregi rózsatő

- Alföldi kamillavirágzat

Eddig, 2007. decemberében a Szegedi téliszalámi kapta meg a földrajzi árujelzős közösségi oltalmat a benyújtott termékek közül.

Fontos tudni, hogy az Európai Unióban csak olyan termék nyerhet védelmet, amelynek hátterében termelői csoportosulás áll, így a kérelem benyújtója és a termékleírás elkészitője már most is az adott terméket élöállítók csoportosulásának kell lennie. A termelöi csoportok és TÉSZ-ek, mint közösségi marketingformák hiánya azonban egyértelmüen akadályozza az ágazati és az országos közösségi marketing hatékony múködését.

A földrajzi nevek védelme nagyon fontos eszközt jelent a vidékfejlesztéshez és a vidék fenntarthatóságának biztosításához, mivel lehetővé teszi a mezőgazdasági termelés diverzifikálását, a hátrányos helyzetü régiók termékeinek népszerúsítését, a termelök jövedelmének növelését, továbbá a fogyasztók elvárásainak figyelembe vételét, akik a mennyiséggel szemben előnyben részesítik a minőséget. Érzékszervi sajátosságaik és elöállítási módjuk megkülönbözteti ezeket a termékeket a globalizált piacon forgalmazott többi terméktől. A fogyasztók számára ezen termékek jól ismert és megbízható forrásból származnak, kielégítették egy tanúsítási rendszer követelményeit, továbbá - származásukból és tradicionális előállitási módjukból kifolyólag - speciális és megkülönböztetett minöséggel rendelkeznek.

\section{HAGYOMÁNYOS ÉS TÁJJELLEGỦ (HÍR) ÉLELMISZEREK}

A fejlett nyugat-európai országokban már az 1980-as évek végétől egyre nagyobb fogyasztói érdeklödés mutatkozik a hagyományos és tájjellegü élelmiszerek iránt, melyek egyedi, különleges minőséget képviselnek.

Az eredetvédelmet szạbályozó 2081/92 EGK és a hagyományos különleges tulajdonság tanúsítási rendszerét megteremtő 2082/92 EGK rendeletek megjelenése után mintegy ezek társadalmi, civil szerveződésü hátteréül - került elindításra az Európai Bizottság által támogatott Euroterroirs Program, az európai régiók hagyományos és tájjellegü élelmiszereinek összegyüjtésére. A gyüjteménybe való bekerülés feltételeinek lényege azonos az eredetvédelmi és a hagyományos különleges tulajdonság tanúsítási rendeletekben 
rögzitettekkel. A feltételeket azonban lazábban, több eltérési lehetőséggel fogalmazták meg. $\mathrm{Ez}$ egyrészröl azon élelmiszerek felvételét is lehetővé teszi, amelyek a rendeletek szigorú kritériumait nem elégítik ki. Másrészröl viszont - miután a gyüjteménybe való felvételt nem a termelönek kell kérnie, hanem a hagyományos termékek összegyüjtése a Program feladata biztosítja, hogy ne „vesszenek el” azon élelmiszerek sem, amelyek védelmére vagy tanúsítására az előállító nem is gondolt.

A magyar mezőgazdasági és élelmiszeripari kultúra több évszázadra visszatekintő hírnevének köszönhetően a Program közép-kelet-európai kiterjesztésébe elöször hazánk kapcsolódhatott be 1998-ban. A „Hagyományok-Ízek-Régiók” (HÍR) program célkitüzése az volt, hogy létrehozza Magyarország hagyományos és tájjellegü mezőgazdasági termékeinek gyüjteményét és elősegítse gazdasági hasznosításukat (Pallóné, 2003).

A különleges minőséget a termék elöállításhoz kötődő táj, történet és kultúra határozza meg, melynek alapján a gyüjteménybe kerülés követelményei a következök voltak:

- az elöállítási mód hagyományossága,

- az adott tájegységhez való kötődés,

- legalább két generációs történeti múlt,

- ismertség az adott térségben,

- ma is létező és forgalmazható termék.

Az így elkészült gyüjtemény Magyarország 300 hagyományos és tájjellegü termékének szakmai-történeti leírását tartalmazza régiónként, és azon belül ágazati bontásban. Ágazati megoszlás szerint a legtöbb termék a termesztett, gyüjtögetett és feldolgozott gyümölcs és zöldségfélék köre. Regionális megoszlás alapján a termékekben leggazdagabb régiók: Dél-Alföld (86 termék), Észak-Alföld (58 termék) és KözépMagyarország (46 termék).

\section{A KÜLÖNLEGES MINŐSÉGÜ ÉLELMISZEREK SZEREPE A VIDÉK FENNTARTHATÓSÁGÁBAN}

A fejlett országok túlkínálati piacain a fogyasztók a különlegességeket, a többitől eltérỏ specialitásokat keresik (hagyományt, karakterisztikus tájegységet, kultúrát). Ilyen minőségi különlegesség eredhet a földrajzi kötődésböl, a termék hagyományos jellegéből vagy az ökológiai módon történő előállításból (Panyor - Marosi, 2006).

Az eredetvédelemmel rendelkező földrajzi ánujelzős élelmiszerek termelése - sok esetben kézmủves jellegü termelés révén - egy nagyobb hozzáadott értéket eredményez. Így érvényesül a multifunkcionalitás elve, mivel a tevékenység a falusi turizmushoz is szorosan kötödik, valamint hozzájárul a hagyományok örzéséhez és a vidéki népesség helyben tartásához. Tehát az eredetvédelmi rendszer révén a hozzáadott érték a régióban marad, növeli a helyi fogyasztást (helyi bemutatók, gasztronómiai fesztiválok, turisztikai rendezvények), munkalehetőséget teremt, lehetőséget nyújt a helyi vállalkozások beindításához, mindezzel megakadályozva a vidéki népesség elnéptelenedését.

Egyértelmủen megállapítható, hogy a hagyományos élelmiszerek jelentős része szorosan illeszkedik az egészséges táplálkozási étrendbe, amely az utóbbi idöszakban egyre jelentősebb vásárlóerőt köt le az élelmiszerpiacon. E piaci szegmens azonosítása és az igények megismerése kiváló gazdasági lehetöséget kínál a gyüjteményben szereplö egyes termékeknek, melyek meghatározóak lehetnek egy-egy régióban élök számára. 
Az egyes régiókban megtermelt ökotermékek iránti igény is jelentős potenciállal bír, hiszen a folyamatosan növekvő biopiacon a fizetőképes kereslet emelkedik. Az élelmiszerbiztonság középpontba kerülésével a fogyasztók számára egyre fontosabbá válnak a megbízható forrásból származó, környezetkímélő módon előállított és biztonságos eredetű, tanúsított élelmiszerek. Az ökotermékek előállítása a különböző régiókban új munkahelyeket teremt, melyen belül az élelmiszeriparhoz kapcsolódó szakirányú emberek iránti kereslet növekedhet. A foglakozások más foglalkozásokat teremtenek, új vállalkozások jöhetnek létre, melynek következtében növekszik a vásárlóerő. A megnövekedett vásárlóerō pedig fellendíti a vendéglátást, az éttermek, hotelek forgalmát.

Tehát a hagyományos termékek és a hagyományos módszerek a fenntartható vidékfejlesztést és a mezögazdasági termékek sokszinnüségét szolgálják.

\section{IRODALOMJEGYZEK}

Eberle, U.-Reuter, W. 2004.: Ernährungswende. Ernährungsrisiken-Identifikation von Handlungsschwerpunkten. Öko-Institut, Hamburg/Freiburg/Darmstadt, 2004. 37-40.p.

Pallóné Kisérdi Imola 2003. Hagyományos és tájjellegü termékeink perspektívái az Európai Unióban, Konzervújság 2003/3. szám 88-91.p.

Panyor Á. - Marosi T. 2006.: Az élelmiszerek eredetvédelmének összefüggése a versenyképességgel. Élelmezési Ipar, LX.évf. 3. szám 93-95.p.

Zobor E. 2004.: Útmutató a földrajzi árujelzők bejegyzését kérelmezők számára - A mezögazdasági termékek és az élelmiszerek eredetmegjelölésének és földrajzi jelzésének oltalma. FVM kiadvány, Budapest 